\title{
Remarkably Mild and Efficient Intramolecular Friedel-Crafts Cyclization Catalyzed by In(III)
}

\author{
Ryuji Hayashi and Gregory R. Cook ${ }^{\star}$ \\ Department of Chemistry and Molecular Biology, North Dakota State University, Fargo, North \\ Dakota 58105-5516
}

\begin{abstract}
Indium(III) salts were found to be highly effective catalysts for the intramolecular Friedel-Crafts reaction of simple allylic bromides and arenes. In(III) salts appear to be the most general and possess unique halophilic properties as a Lewis acid for this reaction among the catalysts evaluated to date. Deactivated arenes possessing chloride, bromide, and fluoride underwent smooth reaction when activated by $\mathrm{InCl}_{3}$.
\end{abstract}

More than 125 years after its inception, electrophilic aromatic substitution (the Friedel-Crafts (FC) reaction) ${ }^{1}$ still remains an important method for $\mathrm{C}-\mathrm{C}$ bond formation and is the subject of continued investigation today. FC reactions traditionally require a stoichiometric amount of strong Lewis acid and severe conditions. ${ }^{2}$ Original conditions have been replaced by milder and more environmentally friendly procedures. While great strides have been made in catalytic FC reactions, there remain several challenges. Particularly reactions with electron deficient arenes are a continued problem with very few solutions. Therefore, new efficient, mild, and catalytic methods to activate electrophiles for Friedel-Crafts reactions are highly significant.

Lately the utility of indium(III) Lewis acids in organic synthesis has received a great deal of interest due to their relatively low toxicity, stability in air and water, and recyclability. ${ }^{3}$ There are a number of examples of catalytic indium(III) salts utilized in Friedel-Crafts reactions including electrophilic aromatic substitution with carbonyl compounds, ${ }^{4}$ sulfuryl chloride, ${ }^{5}$ electron deficient alkene, ${ }^{6}$ alkyne, ${ }^{7}$ aziridine ${ }^{8}$ and epoxide. ${ }^{9}$ These examples are all activated by Lewis acid coordination to strong Lewis basic functionality such as oxygen and nitrogen. Arene additions to allylic halides catalyzed by Lewis acids and indium metal have been shown, 10 however, these reactions require an excess amount of arene to obtain useful yields. Examples of direct halide activation by catalytic Lewis acid are rare; however, as in Friedel and Crafts' original reports, stoichiometric variants have been reported. Alkylation of aromatics with exo-2-chloro and 7-chloronorbornane with stoichiometric amount of Lewis acids $\left(\mathrm{SnCl}_{4}\right.$, $\mathrm{AlCl}_{3}, \mathrm{BF}_{3}$, and $\mathrm{SbF}_{5}$ ) has been demonstrated. ${ }^{11}$ And zinc(II) salts have been reported to activate allyl chlorides for cycloaddition onto alkynes. ${ }^{12}$ Because of the difficulty in achieving catalytic activation of halides, their use in FC reactions has been limited.

We have recently demonstrated a mild and efficient atom transfer cyclization catalyzed by In (III) salts. ${ }^{13}$ Importantly, we found that the reaction was driven by cationic activation of allyl bromide by a catalytic amount of $\mathrm{InCl}_{3}$. As shown in Scheme 1, treatment of $\mathbf{1}$ with catalytic indium chloride in dichloromethane at room temperature resulted in the efficient formation of the atom transfer cyclization product $\mathbf{2}$. This product arose via electrophilic allylation of the alkyne via the polarized species A or the cationic species B. Reasoning that this allylic 
activation would be amenable to FC reactions, we undertook a study to ascertain the effectiveness of In(III) Lewis acids on this reaction. Herein, we disclose a remarkably mild and efficient intramolecular FC cyclization of allylic halide onto a variety of arenes, both electron rich and electron poor, catalyzed by $\operatorname{In}(\mathrm{III})$ salts.

We have discovered that $10 \mathrm{~mol} \%$ of $\mathrm{InCl}_{3}$ in dichloromethane $(0.05 \mathrm{M})$ at room temperature in the presence of molecular sieves efficiently catalyzed the FC cyclization of allylic bromide onto electron rich arene with excellent yield (Table 1, entries 1-6). In the absence of molecular sieves the substrate decomposed. The sieves are thought to be performing the role of a neutral acid scavenger. ${ }^{14}$ Optimal efficiency was observed with $10 \mathrm{~mol} \%$ catalyst loading although $5 \mathrm{~mol} \%$ performed with only slightly diminished yield. The reaction proceeded well in noncoordinating solvents such as dichloromethane, dibromomethane, or toluene, but failed in other common solvents $\left(\mathrm{CHCl}_{3}\right.$, THF, $\mathrm{MeCN}, \mathrm{MeNO}_{2}, \mathrm{EtOH}, \mathrm{MeOH}$, acetone, $\left.\mathrm{H}_{2} \mathrm{O}\right)$. Application of $\mathrm{In}(\mathrm{I})$ salts, $\mathrm{InF}_{3}$ and $\mathrm{In}(\mathrm{OAc})_{3}$ in the reaction resulted in the formation of only a trace of product with recovery of unreacted starting material (entries 10-12).

We next screened a variety of common Lewis acids. Most completely failed to promote the cyclization (Table 1, entries 13-21). However, $\mathrm{SnCl}_{4}, \mathrm{Fe}\left(\mathrm{ClO}_{4}\right)_{3}$, and $\mathrm{Zn}(\mathrm{OTf})_{2}$ showed success in the catalytic activation of 3a (entries 22-24). It is important to note that only indium (III) Lewis acids catalyzed the reaction of arenes that were less electron rich than $\mathbf{3 a}$. $\mathrm{Zn}$ (II), $\mathrm{Fe}(\mathrm{III})$ or $\mathrm{Sn}$ (IV) Lewis acids were ineffective at promoting the cyclization of the activated monomethoxyarene $\mathbf{3 b}$. Thus, of the Lewis acids examined, In(III) salts were unique in their mildness and activity for this FC reaction.

The substrate scope of the reaction under the optimized conditions was investigated and the results are summarized in Table 2 . The reaction was amenable to a wide variety of aromatic rings for the synthesis of benzocarbocycles. ${ }^{15}$ When meta-substituted arenes were employed, regioisomeric products resulted from both para- and ortho-attack of the electrophile.

Remarkably to our great satisfaction, under In(III) catalysis, even electron deactivated arenes possessing a chlorine, fluorine or bromine substituent cyclized smoothly and cleanly in high yield (entries 7-12). However, electron withdrawing groups as strong as $\mathrm{CF}_{3}$ were ineffective in this Friedel-Crafts cyclization. Nitrogen linkers in the tether were agreeable to the FC cyclization as well. Thus, isoquinolone derivatives ${ }^{16}$ were formed in quantitative yields. These reactions performed equally well when other $\mathrm{In}(\mathrm{III})$ salts were employed including $\mathrm{InBr}_{3}$, In $(\mathrm{OTf})_{3}$ and $\mathrm{In}\left(\mathrm{NO}_{3}\right)_{3}$. Although slightly higher catalyst loads $(25 \mathrm{~mol} \%)$ and longer reaction times were required, incredibly even allyl chlorides could be activated by $\mathrm{InCl}_{3}$. This was exemplified by the smooth cyclization of substrate $\mathbf{3 q}$ in $95 \%$ isolated yield (entry 18 ).

In conclusion, we have demonstrated a remarkably mild and efficient Friedel-Crafts cyclization catalyzed by In(III) salts. The reaction was driven by cationic activation of allylic bromide by substoichiometric amount of Lewis acid. In(III) salts appear to be the most general and possess unique halophilic properties as a Lewis acid for this reaction among the catalysts evaluated to date. We are currently examining the scope and limitation of this catalytic activation of halides by indium(III) salts and other metals in order to gain further insight into this distinctive reactivity.

\section{Supplementary Material}

Refer to Web version on PubMed Central for supplementary material.

\section{Acknowledgement}

We are grateful to the National Science Foundation (NSF-CHM-0616485) and the NDSU NIH Center for Protease Research (NCRR-P20-RR15566) for financial support of this project.

Org Lett. Author manuscript; available in PMC 2008 September 25. 


\section{References}

1. a) Friedel C, Crafts JM. C. R. Hebd. Seances Acad. Sci 1877;84:1392. b) Friedel C, Crafts JM. C. R. Hebd. Seances Acad. Sci 1877;84:1450.

2. Olah, GA. Friedel-Crafts and Related Reactions. New York: Wiley; 1963. Olah, GA. Friedel-Crafts Chemistry. New York: Wiley; 1973. Roberts, RM.; Khalaf, AA. Friedel-Crafts Alkylation Chemistry. A Century of Discovery. New York: Marcel Dekker; 1984. Olah, GA.; Krishnamurti, R.; Surya Prakash, GK. Comprehensive Organic Synthesis. 1st ed.. Vol. 3. New York: Pergamon; 1991. p. 293-339. e) Bandini M, Melloni A, Umani-Ronchi A. Angew. Chem. Int. Ed 2004;43:550-556. f) Bandini M, Emer E, Tommasi S, Umani-Ronchi A. Eur. J. Org. Chem 2006:3527.

3. Reviews for indium Lewis acids: a) Frost CG, Chauhan KK. J. Chem. Soc. Perkin Trans 2000;1:3015. b) Fringuelli F, Piermatti O, Pizzo F, Vaccaro L. Curr. Org. Chem 2003;7:1661. c) Frost CG, Hartley JP. Mini-Reviews in Organic Chemistry 2004;1:1.

4. a) Babu G, Sridhar N, Perumal PT. Synth. Commun 2000;30:1609. b) Chapman CJ, Frost CG, Hartley JP, Whittle AJ. Tetrahedron Lett 2001;42:773. c) Nagarajan R, Perumal PT. Tetrahedron 2002;58:1229.

5. a) Frost CG, Hartley JP, Whittle AJ. Synlett 2001:830. b) Frost CG, Hartley JP, Griffin D. Tetrahedron Lett 2002;43:4789.

6. a) Yadav JS, Abraham S, Reddy BVS, Sabitha G. Synthesis 2001:2165. b) Yadav JS, Abraham S, Reddy BVS, Sabitha G. Tetrahedron Lett 2001;42:8063. c) Bandini M, Cozzi PG, Giacomini M, Melchiorre P, Selva S, Umani-Ronchi A. J. Org. Chem 2002;67:5386. [PubMed: 12126434] d) Bandini M, Melchiorre P, Melloni A, Umani-Ronchi A. Synthesis 2002:1110.

7. Tsuchimoto T, Maeda T, Shirakawa E, Kawakami Y. Chem. Commun 2000:1573.

8. a) Yadav JS, Reddy BVS, Abraham S, Sabitha G. Tetrahedron Lett 2001;42:8067. b) Yadav JS, Reddy BVS, Mahesh Kumar G, Madan C. Synlett 2001;11:1781.

9. a) Yadav JS, Reddy BVS, Mahesh Kumar G, Madan C. Synlett 2001;11:1781. b) Yadav JS, Reddy BVS, Parimala G. Synlett 2002;7:1143.

10. a) Ichihara J. Chem. Commun 1997:1921. b) Lim HJ, Keum G, Kang SB, Kim Y. Tetrahedron Lett 1999;40:1547.

11. a) Olah GA, Lee CS, Prakash GKS, Moriarty RM, Rao MSC. J. Am. Chem. Soc 1993;115:10728. b) Olah GA, Lee CS, Prakash GKS. J. Org. Chem 1994;59:2590.

12. Miller A, Moore M. Tetrahedron Lett 1980;21:577.

13. Cook GR, Hayashi R. Org. Lett 2006;8:1045. [PubMed: 16524264]

14. Padwa A, Ginn JD, Bur SK, Eidell CK, Lynch SM. J. Org. Chem 2002;67:3412. [PubMed: 12003554]

15. a) Palmer DC, Strauss MJ. Chem. Rev 1977;77:1.Dictionary of Natural Products. Vol 1. London:

Chapman \& Hall; 1994. p. 812 c) Kuramoto M, Yamada K, Shikano M, Yazawa K, Arimoto H, Okamura T, Uemura D. Chem Lett 1997:885.

16. Bentley, KW. The Isoquinoline Alkaloids. Amsterdam: Harwood Academic; 1998.

Org Lett. Author manuscript; available in PMC 2008 September 25. 

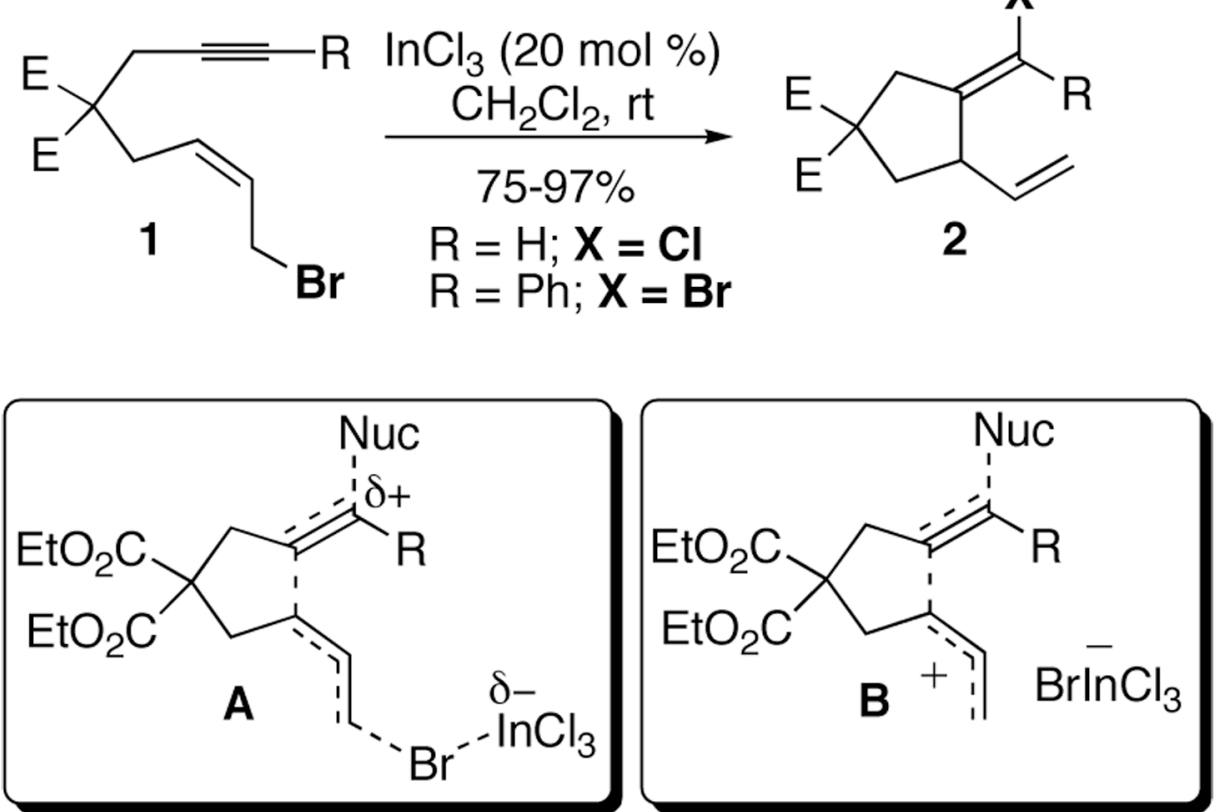

Scheme 1. 
Table 1

Lewis Acid Catalyzed Friedel-Crafts Cyclization ${ }^{a}$

\begin{tabular}{|c|c|c|c|c|}
\hline & $3 a$ & $\begin{array}{l}\stackrel{\mathrm{LA}, 4 \AA \mathrm{MS}}{\mathrm{S}, 4 \mathrm{M})} \\
\underset{\mathrm{rt}, 16 \mathrm{~h}}{\mathrm{E}=\left(\mathrm{EtO}_{2} \mathrm{C}\right)_{2} \mathrm{C}}\end{array}$ & $4 a$ & \\
\hline entry & LA (mol \%) & & solvent & yield $^{b}$ \\
\hline 1 & $\mathrm{InCl}_{3}(5)$ & & $\mathrm{CH}_{2} \mathrm{Cl}_{2}$ & $79 \%$ \\
\hline 2 & $\mathrm{InCl}_{3}(5)$ & & Toluene & $81 \%$ \\
\hline 3 & $\mathrm{InCl}_{3}(10)$ & & $\mathrm{CH}_{2} \mathrm{Cl}_{2}$ & $\mathbf{8 8 \%}$ \\
\hline 4 & $\mathrm{InCl}_{3}(10)$ & & Toluene & $87 \%$ \\
\hline 5 & $\mathrm{InCl}_{3}(10)$ & & $\mathrm{CH}_{2} \mathrm{Br}_{2}$ & $91 \%$ \\
\hline 6 & $\mathrm{InCl}_{3}(10)$ & & $\mathrm{ClCH}_{2} \mathrm{CH}_{2} \mathrm{Cl}$ & $76 \%$ \\
\hline 7 & $\operatorname{InBr}_{3}(10)$ & & $\mathrm{CH}_{2} \mathrm{Cl}_{2}$ & $84 \%$ \\
\hline 8 & $\operatorname{In}(\mathrm{OTf})_{3}(10)$ & & $\mathrm{CH}_{2} \mathrm{Cl}_{2}$ & $82 \%$ \\
\hline 9 & $\mathrm{In}\left(\mathrm{NO}_{3}\right)_{3}(10)$ & & $\mathrm{CH}_{2} \mathrm{Cl}_{2}$ & $77 \%$ \\
\hline 10 & $\operatorname{Inl}(10)$ & & $\mathrm{CH}_{2} \mathrm{Cl}_{2}$ & $\operatorname{trace}^{c}$ \\
\hline 11 & $\operatorname{InF}_{3}(10)$ & & $\mathrm{CH}_{2} \mathrm{Cl}_{2}$ & $\operatorname{trace}^{c}$ \\
\hline 12 & $\mathrm{In}(\mathrm{OAc})_{3}(10)$ & & $\mathrm{CH}_{2} \mathrm{Cl}_{2}$ & $\operatorname{trace}^{c}$ \\
\hline 13 & $\mathrm{AlCl}_{3}(20)$ & & $\mathrm{CH}_{2} \mathrm{Cl}_{2}$ & $0 \%^{c}$ \\
\hline 14 & $\mathrm{Sc}(\mathrm{OTf})_{3}(20)$ & & $\mathrm{CH}_{2} \mathrm{Cl}_{2}$ & $0 \% c$ \\
\hline 15 & $\mathrm{Cu}(\mathrm{OTf})_{2}(20)$ & & $\mathrm{CH}_{2} \mathrm{Cl}_{2}$ & $0 \%^{c}$ \\
\hline 16 & $\operatorname{Mg}(\mathrm{OTf})_{2}(20)$ & & $\mathrm{CH}_{2} \mathrm{Cl}_{2}$ & $0 \% c$ \\
\hline 17 & $\mathrm{ZrCl}_{4}(20)$ & & $\mathrm{CH}_{2} \mathrm{Cl}_{2}$ & $0 \% c$ \\
\hline 18 & $\mathrm{Y}(\mathrm{OTf})_{3}(20)$ & & $\mathrm{CH}_{2} \mathrm{Cl}_{2}$ & $0 \% c$ \\
\hline 19 & $\operatorname{AgOTf}(20)$ & & $\mathrm{CH}_{2} \mathrm{Cl}_{2}$ & $0 \% c$ \\
\hline 20 & $\mathrm{La}(\mathrm{OTf})_{3}(20)$ & & $\mathrm{CH}_{2} \mathrm{Cl}_{2}$ & $0 \% c$ \\
\hline 21 & $\operatorname{Sm}(\mathrm{OTf})_{3}(20)$ & & $\mathrm{CH}_{2} \mathrm{Cl}_{2}$ & $0 \% c$ \\
\hline 22 & $\mathrm{SnCl}_{4}(20)$ & & $\mathrm{CH}_{2} \mathrm{Cl}_{2}$ & $80 \%$ \\
\hline 23 & $\mathrm{Fe}\left(\mathrm{ClO}_{4}\right)_{3}(20)$ & & $\mathrm{CH}_{2} \mathrm{Cl}_{2}$ & $75 \%$ \\
\hline 24 & $\mathrm{Zn}(\mathrm{OTf})_{2}(20)$ & & $\mathrm{CH}_{2} \mathrm{Cl}_{2}$ & $95 \%$ \\
\hline
\end{tabular}

\footnotetext{
${ }^{a}$ Substrate, solvent, 4 A MS, and catalyst were stirred together at rt in a screwcap scintillation vial for $16 \mathrm{~h}$.

${ }^{b}$ Yield of isolated product.

${ }^{c}$ Starting material was recovered intact.
} 
Table 2

Substrate Scope in the Lewis Acid Catalyzed Friedel-Crafts Cyclization ${ }^{a}$

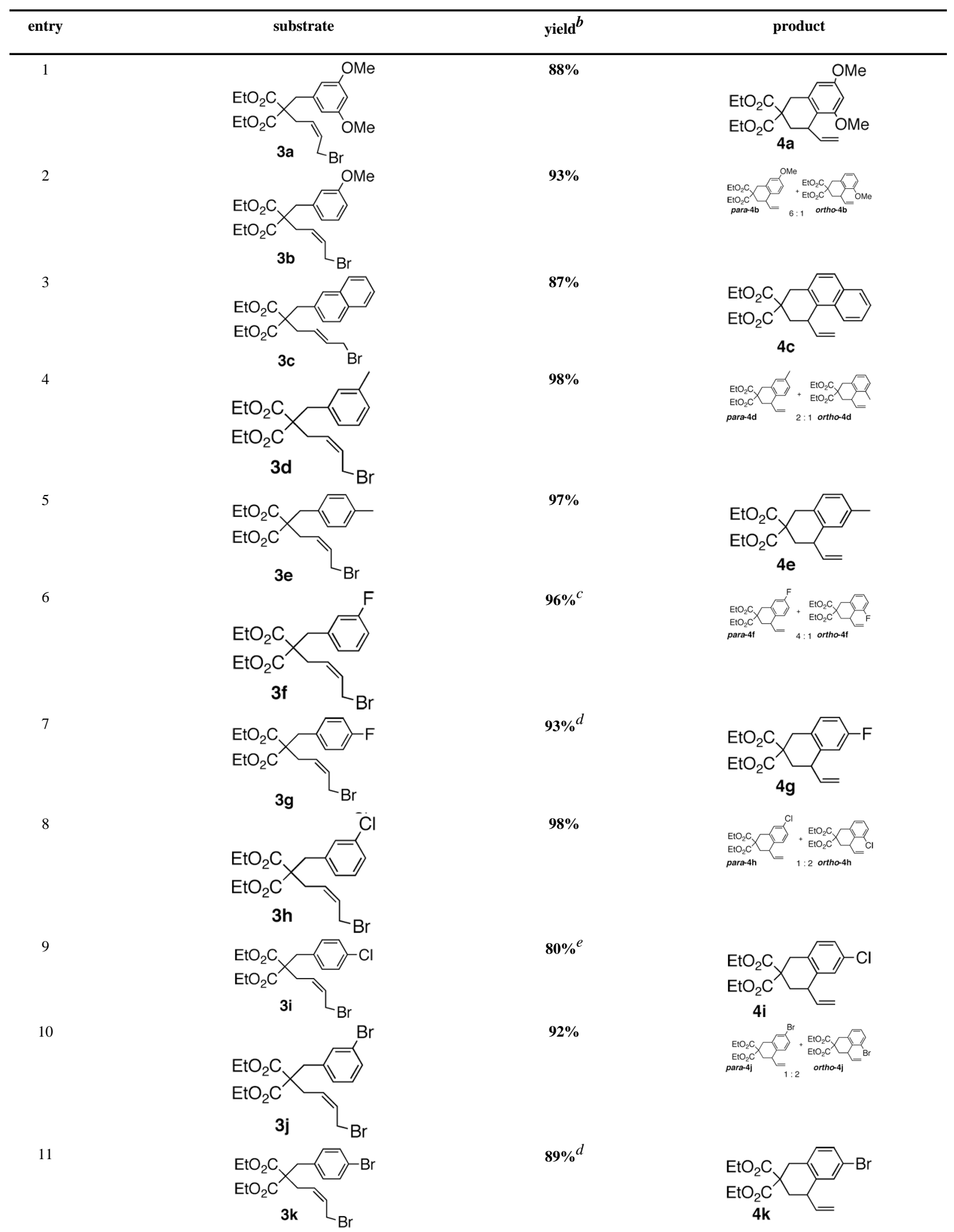

Org Lett. Author manuscript; available in PMC 2008 September 25. 


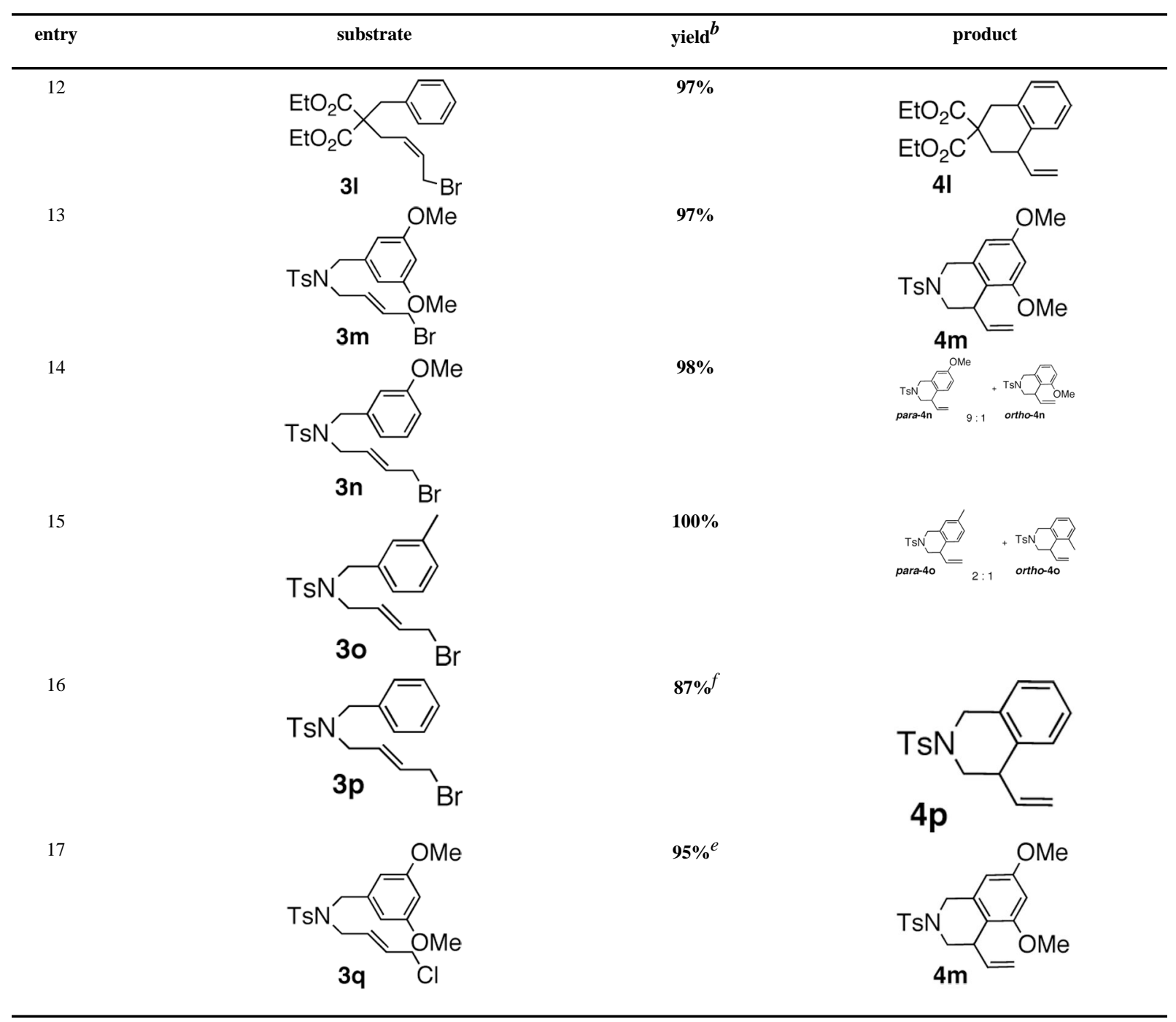

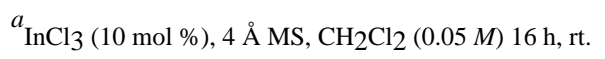

${ }^{b}$ Yield of isolated product.

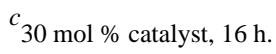

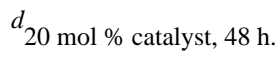

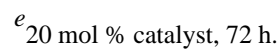

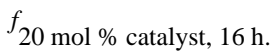

